ORIGINAL ARTICLE

\title{
Efficacy and Tolerability of the Bevacizumab/carboplatin/paclitaxel Combination Therapy as First-line or Non-first-line Therapy for Non-small-cell Lung Cancer
}

\author{
Makoto Nakashima1,2; Ryoko Ohnishi3; Mizuho Kobayashi; Toshitaka Suzuki3; \\ Shigeo Yasuda3; Kimiyasu Sano3; Takuya Goto1; \\ Nobuyuki Mishima1; Tatsuo Kato3; Tadashi Sugiyama²
}

\begin{abstract}
Objective. Bevacizumab/carboplatin / paclitaxel (BEV-CP) combination therapy extends the progression-free survival (PFS) of chemotherapy-naive patients with non-small-cell lung cancer. However, the efficacy and tolerability of BEV-CP therapy in patients with a history of chemotherapy have not been investigated. In the present study, patients receiving BEV-CP therapy at the Nagara Medical Center were divided into 2 groups. Methods. The first-line therapy (FLT) group consisted of 18 patients who had never received chemotherapy before treatment with BEV-CP, and the nonFLT group included 13 patients who had received other chemotherapy regimens before BEV-CP therapy. The efficacy and tolerability of BEV-CP therapy in the FLT and non-FLT groups were analyzed retrospectively. Results. The response rate (RR) was $72.2 \%$ in the FLT group and $61.5 \%$ in the non-FLT group, whereas the disease control rate (DCR) was $83.3 \%$ in the FLT group
\end{abstract}

and $92.3 \%$ in the non-FLT group. However, neither RR nor DCR was statistically significant between the FLT and non-FLT groups ( $\mathrm{p}=0.40$ and 0.43 , respectively). The median PFS time was 240 days in the FLT group and 258 days in the non-FLT group, which was not statistically significant $(\mathrm{p}=0.84)$. The rate of discontinuation of BEV-CP therapy because of adverse effects was $22.2 \%$ in the FLT group and $7.7 \%$ in the non-FLT group. The discontinuation rate was lower in the nonFLT group than in the FLT group, but the difference was not statistically significant $(\mathrm{p}=0.28)$. Conclusion. The efficacy and tolerability of BEV-CP therapy as nonFLT and FLT were comparable.

(JJLC. 2012;52:1007-1016)

KEY WORDS — Non-small-cell lung cancer, Bevacizumab, Second-line therapy, Carboplatin/paclitaxel combination therapy

\section{INTRODUCTION}

Bevacizumab (BEV) is an anti-vascular endothelial growth factor monoclonal antibody. BEV was originally approved for use in colon and rectal cancers and, later for the treatment of non-small-cell lung cancer (NSCLC) except for squamous cell carcinoma, in combination with carboplatin (CBDCA) and paclitaxel (PTX), ${ }^{1}$ or gemcitabine and cisplatin. ${ }^{2}$ The implementation of mainte- nance therapy, based on the administration of BEV after the completion of combination therapy, was reported to extend progression-free survival (PFS) compared with combination therapy without $\mathrm{BEV} .^{1}$ As a result, $\mathrm{BEV}$ was approved for use in NSCLC. However, these clinical trials were conducted in chemotherapy-naive patients and data on the efficacy and the tolerability of BEV administered as second-line therapy are extremely limited.

In the Nagara Medical Center, when NSCLC patients
1Department of Pharmacy, Nagara Medical Center, Japan; ${ }^{2}$ Laboratory of Pharmacy Practice and Social Science, Gifu Pharmaceutical University, Japan; ${ }^{3}$ Department of Respiratory Medicine, Nagara Medical Center, Japan.
Reprints: Makoto Nakashima, Department of Pharmacy, Nagara Medical Center, 1300-7 Nagara, Gifu-shi, Gifu 502-8585, Japan (email:mak-naka@nagara.hosp.go.jp).

Received April 26, 2012; accepted November 5, 2012. 


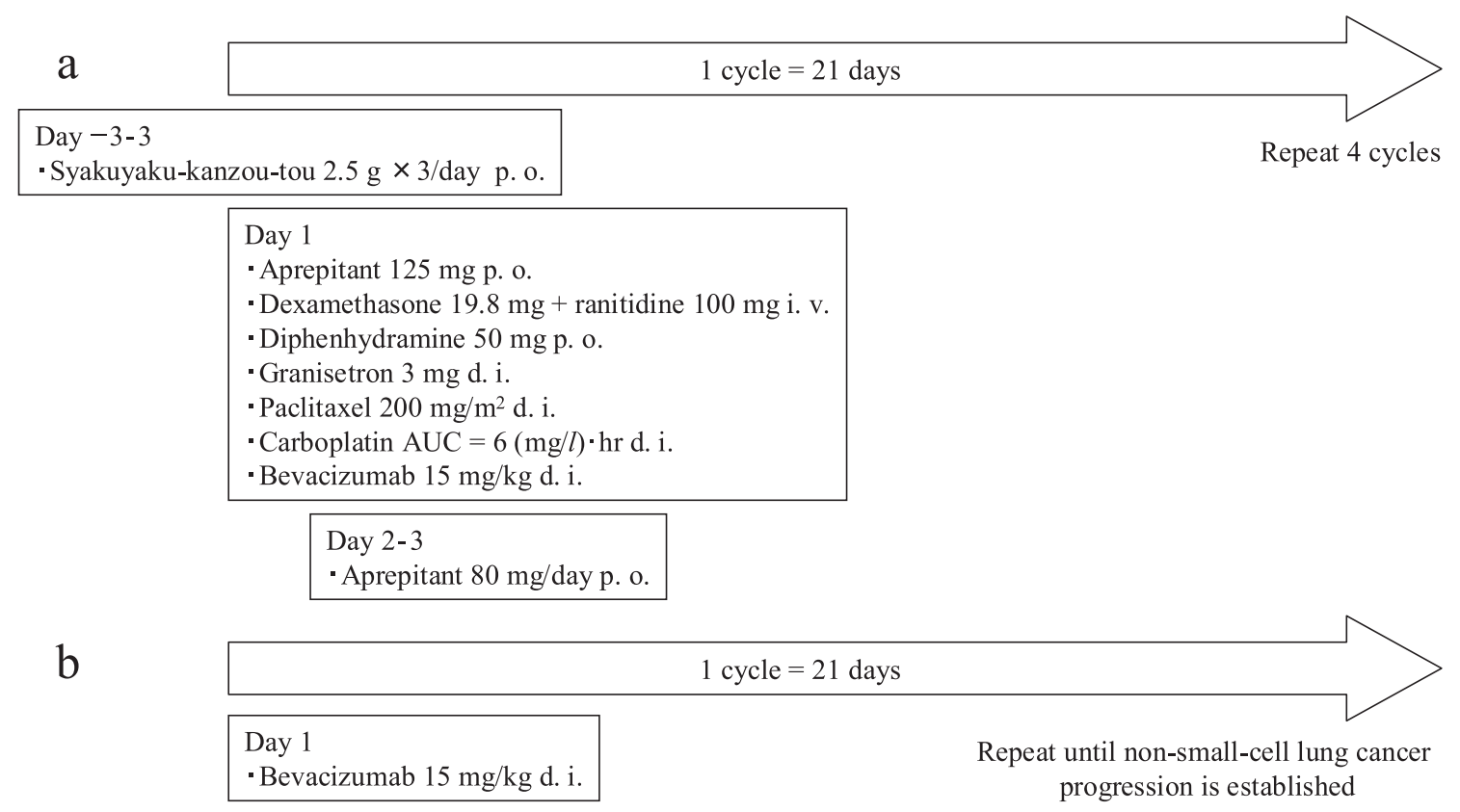

Figure 1. Schedule of bevacizumab/carboplatin/paclitaxel combination therapy and maintenance therapy using bevacizumab. a. Schedule of bevacizumab/carboplatin/paclitaxel combination therapy. b. Schedule of maintenance therapy using bevacizumab. Syakuyaku-kanzou-tou is administered to palliate myalgia caused by paclitaxel. AUC means area under the blood time-concentration curve. p. o. means per os. i. v. means intravenous injection. d. i. means drip infusion.

did not respond to chemotherapy, NSCLC patients were assessed for brain metastasis and tumor sites to determine the indications for BEV. If the risk of hemorrhage ${ }^{3}$ was determined to be low and BEV administration was considered a possibility, the attending physicians discussed the usefulness and the possible adverse effects of the combination therapy with BEV with the eligible patients. If a patient agreed to the treatment with BEV, the physician initiated a BEV regimen while carefully monitoring its efficacy and adverse effects. Based on evidence of the effectiveness of the combination therapy with BEV, CBDCA, and PTX (BEV-CP therapy), this combination was the most frequently used treatment regimen in our center.

The patients included in the present study were divided into 2 groups based on whether or not they had received prior chemotherapy, and the efficacy and the tolerability of BEV-CP therapy were compared between the 2 groups.

\section{PATIENTS AND METHODS}

\section{Patients}

The NSCLC patients who started and completed the
BEV-CP therapy at Nagara Medical Center from January 2010 to August 2011 were included in the study. The patients were divided into 2 groups: the first-line therapy (FLT) group consisted of chemotherapy-naive patients, and the non-FLT group consisted of patients who had been treated with other chemotherapy regimens before starting the BEV-CP therapy. The patients' clinical records were retrospectively reviewed to assess patient background, BEV, CBDCA, and PTX doses, the efficacy and adverse effects of BEV-CP therapy.

The present study was conducted according to the ethical guidelines for clinical trials and was approved by the ethics committee of our center (approval no. 10-6).

\section{Therapy schedule}

The schedules of the BEV-CP therapy and maintenance $\mathrm{BEV}$ therapy after combination regimen are shown in Figure 1. Combination therapy with 4 cycles of platinum doublet for advanced NSCLC was recommended by the 2003 Japan Lung Cancer Society (JLCS) guidelines. ${ }^{4}$ Therefore, we gave of BEV-CP therapy and maintenance therapy was administered after 4 cycles of BEV$\mathrm{CP}$ therapy until disease progression or unacceptable toxicity. 
Table 1. Patient Background

\begin{tabular}{|c|c|c|c|}
\hline & $\begin{array}{l}\text { First-line } \\
\text { therapy group }\end{array}$ & $\begin{array}{l}\text { Non-first-line } \\
\text { therapy group }\end{array}$ & $\mathrm{p}$ value \\
\hline $\mathrm{n}$ & 18 & 13 & \\
\hline Age (years)*1 & $64.7 \pm 9.7$ & $67.2 \pm 11.6$ & $0.53 * 4$ \\
\hline Male/Female & $13 / 5$ & $9 / 4$ & $0.58 * 5$ \\
\hline Histlogical classification (adeno/large cell/adeno or large cell) & $15 / 0 / 3$ & $12 / 1 / 0$ & $0.63 * 6$ \\
\hline Clinical stage (stage IIB/IIIA/IIIB/IV) & $1 / 3 / 3 / 11$ & $0 / 1 / 1 / 11$ & $0.25 * 6$ \\
\hline ECOG performance status $(0 / 1 / 2)$ & $7 / 10 / 1$ & $3 / 8 / 2$ & $0.33 * 6$ \\
\hline State of EGFR gene mutation (mutated/not mutated/unknown) & $3 / 12 / 3$ & $2 / 6 / 5$ & $0.37 * 6$ \\
\hline Patient with a history of hypertension (exist/never) & $7 / 11$ & $5 / 8$ & $0.64 * 5$ \\
\hline Body weight $(\mathrm{kg})^{* 1}$ & $58.5 \pm 10.8$ & $57.5 \pm 9.3$ & $0.79 * 4$ \\
\hline Body surface area $\left(\mathrm{m}^{2}\right)^{* 1}$ & $1.57 \pm 0.18$ & $1.56 \pm 0.15$ & $0.80 * 4$ \\
\hline Creatinine clearance $(\mathrm{ml} / \mathrm{min}) * 1$ & $98.4 \pm 23.3$ & $75.6 \pm 26.4$ & $0.02 * 4$ \\
\hline Number of regimens received $(1 / 2 / \geq 3) * 2$ & - & $4 / 4 / 5$ & \\
\hline $\begin{array}{l}\text { Elapsed number of days between the last day of previous } \\
\text { treatment and the beginning of BEV-CP therapy*1 }\end{array}$ & - & $212.8 \pm 186.3$ & \\
\hline \multicolumn{4}{|l|}{ Bevacizumab/carboplatin/paclitaxel combination therapy } \\
\hline Number of cycles*1 & $3.4 \pm 1.2$ & $3.8 \pm 0.4$ & $0.63 * 6$ \\
\hline \multicolumn{4}{|l|}{ Relative dose intensity } \\
\hline$\cdot$ Bevacizumab*1 & $0.96 \pm 0.08$ & $0.87 \pm 0.16$ & $0.06 * 6$ \\
\hline$\cdot$ Carboplatin*1 & $0.91 \pm 0.14$ & $0.78 \pm 0.17$ & $0.04 * 6$ \\
\hline$\cdot$ Paclitaxel*1 $^{* 1}$ & $0.86 \pm 0.12$ & $0.77 \pm 0.15$ & $0.15 * 6$ \\
\hline Average relative dose intensity & $0.91 \pm 0.11$ & $0.80 \pm 0.15$ & $0.01 * 6$ \\
\hline \multicolumn{4}{|l|}{ Maintenance therapy } \\
\hline Number of cycles*1 & $4.9 \pm 4.5$ & $5.1 \pm 5.7$ & $0.78 * 6$ \\
\hline \multicolumn{4}{|l|}{ Relative dose intensity } \\
\hline · Bevacizumab*1,3 & $0.97 \pm 0.05$ & $0.92 \pm 0.12$ & $0.15^{* 6}$ \\
\hline Status of therapy (ongoing/finished) & $3 / 15$ & $4 / 9$ & $0.31 * 5$ \\
\hline
\end{tabular}

ECOG: Eastern Cooperative Oncology Group, BEV-CP therapy: Bevacizumab/carboplatin/paclitaxel combination therapy.

${ }^{* 1}$ : Mean \pm S.D. $* 2$ : Adjuvant chemotherapy and epidermal growth factor receptor tyrosine kinase inhibitor were counted as 1 regimen. ${ }^{*}$ : Not calculated in patients who did not receive maintenance therapy (4 patients in both groups). *4: Student $t$ test. *5: Fisher exact probability test. *6: Mann-Whitney $U$ test.

\section{Efficacy}

Tumor size was measured on computed tomographic images obtained after 2 and 4 cycles of the BEV-CP therapy, and the effects were determined using the Response Evaluation Criteria in Solid Tumors Version 1.1. The response rate $(\mathrm{RR}$; complete response + partial response) and the disease control rate (DCR; complete response + partial response + stable disease) were compared between the FLT and non-FLT groups. Furthermore, PFS was calculated from the start of treatment to disease progression, and the PFS times were compared between the 2 groups.

\section{Adverse effects}

The occurrence of adverse effects due to BEV-CP therapy and the maintenance therapy were determined in the FLT and non-FLT groups. The occurrence rate of all grades of adverse effects and those higher than grade 3 were compared between the FLT and non-FLT groups, using the Common Terminology Criteria for Adverse Events Version 4.0. In addition, the rates of BEV$\mathrm{CP}$ therapy discontinuation due to adverse effects were compared between the FLT and non-FLT groups.

\section{Statistical analysis}

The Fisher exact probability test, the Mann-Whitney $U$ test and the Student $t$ test were used to compare the patient backgrounds between the FLT and non-FLT groups. The effectiveness, occurrence rate of adverse effects, and rate of BEV-CP therapy discontinuation due to adverse effects were analyzed using the Fisher exact probability test. Kaplan-Meier graphs were generated for PFS, and the log-rank test was used to compare the PFS time between the 2 groups. All statistical calcula- 
Table 2-a. Drugs Administered to the Non-first-line Therapy Group Before the Administration of Bevacizumab/carboplatin/paclitaxel Combination Therapy (Case No. 1-6).

\begin{tabular}{|c|c|c|c|c|c|c|c|}
\hline $\begin{array}{l}\text { Case } \\
\text { no. }\end{array}$ & $\begin{array}{l}\text { Previously treated } \\
\text { regimen }\end{array}$ & Dose & Cycles & $\begin{array}{l}\text { Cytore- } \\
\text { ductive } \\
\text { effect }\end{array}$ & $\begin{array}{l}\text { Re- } \\
\text { sponse } \\
\text { rate }(\%)\end{array}$ & $\begin{array}{l}\text { Reason for } \\
\text { completion of } \\
\text { therapy }\end{array}$ & $\begin{array}{c}\text { Days from completion } \\
\text { of therapy to starting } \\
\text { BEV-CP therapy }\end{array}$ \\
\hline 1 & Carboplatin/Paclitaxel* & $\begin{array}{c}\text { Carboplatin: } \\
\text { AUC }=5.7(\mathrm{mg} / \mathrm{l}) \cdot \mathrm{hr} \\
\text { Paclitaxel: } 159.6 \mathrm{mg} / \mathrm{m}^{2}\end{array}$ & 2 cycles & PR & 100 & $\begin{array}{l}\text { Completion of } \\
\text { designed cycles }\end{array}$ & 378 \\
\hline \multirow[t]{2}{*}{2} & Carboplatin/Paclitaxel & $\begin{array}{c}\text { Carboplatin: } \\
\text { AUC }=6.0(\mathrm{mg} / \mathrm{l}) \cdot \mathrm{hr} \\
\text { Paclitaxel: } 198.8 \mathrm{mg} / \mathrm{m}^{2}\end{array}$ & 4 cycles & PR & \multirow[t]{2}{*}{50.0} & $\begin{array}{l}\text { Completion of } \\
\text { designed cycles }\end{array}$ & 322 \\
\hline & Pemetrexed & $500 \mathrm{mg} / \mathrm{m}^{2}$ & 4 cycles & $\mathrm{SD}$ & & $\begin{array}{l}\text { Completion of } \\
\text { designed cycles }\end{array}$ & 137 \\
\hline \multirow{6}{*}{3} & Carboplatin/Paclitaxel & $\begin{array}{c}\text { Carboplatin: } \\
\text { AUC }=6.0(\mathrm{mg} / l) \cdot \mathrm{hr} \\
\text { Paclitaxel: } 210.5 \mathrm{mg} / \mathrm{m}^{2}\end{array}$ & 4 cycles & PR & \multirow{6}{*}{16.7} & $\begin{array}{l}\text { Completion of } \\
\text { designed cycles }\end{array}$ & 1112 \\
\hline & Carboplatin/Paclitaxel & $\begin{array}{c}\text { Carboplatin: } \\
\text { AUC }=6.0(\mathrm{mg} / \mathrm{l}) \cdot \mathrm{hr} \\
\text { Paclitaxel: } 175.4 \mathrm{mg} / \mathrm{m}^{2}\end{array}$ & 4 cycles & $\mathrm{SD}$ & & $\begin{array}{l}\text { Completion of } \\
\text { designed cycles }\end{array}$ & 790 \\
\hline & Docetaxel & $70.2 \mathrm{mg} / \mathrm{m}^{2}$ & 4 cycles & $\mathrm{PD}$ & & $\begin{array}{c}\text { Disease } \\
\text { progression }\end{array}$ & 574 \\
\hline & Carboplatin/Gemcitabine & $\begin{array}{c}\text { Carboplatin: } \\
\text { AUC }=2.0(\mathrm{mg} / \mathrm{l}) \cdot \mathrm{hr} \\
\text { Gemcitabine: } 983.0 \mathrm{mg} / \mathrm{m}^{2}\end{array}$ & 2 cycles & $\mathrm{PD}$ & & $\begin{array}{c}\text { Disease } \\
\text { progression }\end{array}$ & 455 \\
\hline & Cisplatin/S-1 & $\begin{array}{l}\text { Cisplatin: } 56.2 \mathrm{mg} / \mathrm{m}^{2} \\
\text { S-1: } 120 \mathrm{mg} / \text { body }\end{array}$ & 4 cycles & PD & & $\begin{array}{l}\text { Disease } \\
\text { progression }\end{array}$ & 315 \\
\hline & Pemetrexed & $499.2 \pm 5.2 \mathrm{mg} / \mathrm{m}^{2}$ & 4 cycles & $\mathrm{SD}$ & & $\begin{array}{l}\text { Completion of } \\
\text { designed cycles }\end{array}$ & 70 \\
\hline 4 & Carboplatin/Paclitaxel* & $\begin{array}{c}\text { Carboplatin: } \\
\text { AUC }=4.7(\mathrm{mg} / \mathrm{l}) \cdot \mathrm{hr} \\
\text { Paclitaxel: } 140.5 \mathrm{mg} / \mathrm{m}^{2}\end{array}$ & 2 cycles & PR & 100 & $\begin{array}{l}\text { Completion of } \\
\text { designed cycles }\end{array}$ & 176 \\
\hline \multirow[b]{2}{*}{5} & Carboplatin/Paclitaxel & $\begin{array}{c}\text { Carboplatin: } \\
\mathrm{AUC}=5.9(\mathrm{mg} / \mathrm{l}) \cdot \mathrm{hr}\end{array}$ & 4 cycles & PR & \multirow[b]{2}{*}{100} & $\begin{array}{l}\text { Completion of } \\
\text { designed cycles }\end{array}$ & 356 \\
\hline & Gefitinib & $\begin{array}{c}\text { Paclitaxel: } 172.4 \mathrm{mg} / \mathrm{m}^{2} \\
250 \mathrm{mg} / \text { body }\end{array}$ & 281 days & PR & & $\begin{array}{c}\text { Disease } \\
\text { progression }\end{array}$ & 8 \\
\hline 6 & Carboplatin/Paclitaxel & $\begin{array}{c}\text { Carboplatin: } \\
\text { AUC }=6.1(\mathrm{mg} / \mathrm{l}) \cdot \mathrm{hr} \\
\text { Paclitaxel: } 200.0 \mathrm{mg} / \mathrm{m}^{2}\end{array}$ & 4 cycles & PR & 100 & $\begin{array}{l}\text { Completion of } \\
\text { designed cycles }\end{array}$ & 256 \\
\hline
\end{tabular}

* This therapy was conducted followed by 2 cycles of weekly carboplatin/paclitaxel concurrent radiation therapy.

S-1, combination capsule that contains tegafur, gimeracil, and oteracil potassium. Dose of S-1 indicated tegafur dose.

AUC, area under the blood time-concentration curve; BEV-CP, combination therapy with bevacizumab/carboplatin/paclitaxel; PR, partial response; $\mathrm{SD}$, stable disease; $\mathrm{PD}$, progressive disease.

tions were performed using Statcel 2 software, and the level of significance was set as $\mathrm{p}<0.05$.

\section{RESULTS}

\section{Patient backgrounds}

The backgrounds of the patients in the FLT and nonFLT groups are shown in Table 1 . There were 18 patients in the FLT group and 13 in the non-FLT group. Three patients in the FLT group and 4 patients in the non-FLT group completed the course of the BEV-CP therapy and had begun or were about to start maintenance therapy as of September 1, 2011. The creatinine clearance in the non-FLT group was significantly lower than that in the FLT group $(\mathrm{p}=0.02)$. The relative dose intensity (RDI) of each drug and the average-RDI for BEV-CP therapy in the non-FLT group were lower than those in the FLT group, and the RDI of CBDCA and the average-RDI were statistically significant $(\mathrm{p}=0.04$ and 0.01 , respectively).

The previous chemotherapy regimens in the non-FLT group are shown in Table 2. CBDCA and PTX combination therapy was the most frequently administered regimen and was reported in 12 (92.3\%) of the 13 patients. 
Table 2-b. Drugs Administered to the Non-first-line Therapy Group Before the Administration of Bevacizumab/carboplatin/paclitaxel Combination Therapy (Case No. 7-9).

\begin{tabular}{|c|c|c|c|c|c|c|c|}
\hline $\begin{array}{l}\text { Case } \\
\text { no. }\end{array}$ & $\begin{array}{l}\text { Previously treated } \\
\text { regimen }\end{array}$ & Dose & Cycles & $\begin{array}{l}\text { Cytore- } \\
\text { ductive } \\
\text { effect }\end{array}$ & $\begin{array}{l}\text { Re- } \\
\text { sponse } \\
\text { rate (\%) }\end{array}$ & $\begin{array}{l}\text { Reason for } \\
\text { completion of } \\
\text { therapy }\end{array}$ & $\begin{array}{c}\text { Days from completion } \\
\text { of therapy to starting } \\
\text { BEV-CP therapy }\end{array}$ \\
\hline \multirow{2}{*}{7} & Cisplatin/Docetaxel & $\begin{array}{l}\text { Cisplatin: } 79.9 \mathrm{mg} / \mathrm{m}^{2} \\
\text { Docetaxel: } 59.7 \mathrm{mg} / \mathrm{m}^{2}\end{array}$ & 6 cycles & $\mathrm{PR}$ & \multirow{2}{*}{100} & $\begin{array}{l}\text { Completion of } \\
\text { designed cycles }\end{array}$ & 636 \\
\hline & Gefitinib & $250 \mathrm{mg} /$ body & 609 days & PR & & $\begin{array}{l}\text { Disease } \\
\text { progression }\end{array}$ & 6 \\
\hline \multirow{8}{*}{8} & $\begin{array}{l}\text { Carboplatin/Paclitaxel* } \\
\text { (induction therapy) }\end{array}$ & $\begin{array}{c}\text { Carboplatin: } \\
\text { AUC }=5.0(\mathrm{mg} / \mathrm{l}) \cdot \mathrm{hr} \\
\text { Paclitaxel: } 174.7 \mathrm{mg} / \mathrm{m}^{2}\end{array}$ & 2 cycles & $\mathrm{SD}$ & \multirow{8}{*}{0} & $\begin{array}{l}\text { Completion of } \\
\text { designed cycles }\end{array}$ & 1310 \\
\hline & Carboplatin/Paclitaxel & $\begin{array}{c}\text { Carboplatin: } \\
\text { AUC }=5.9(\mathrm{mg} / \mathrm{l}) \cdot \mathrm{hr} \\
\text { Paclitaxel: } 200.0 \mathrm{mg} / \mathrm{m}^{2}\end{array}$ & 2 cycles & $\mathrm{SD}$ & & $\begin{array}{l}\text { Inadequate } \\
\text { effect }\end{array}$ & 1128 \\
\hline & Gemcitabine/Vinorelbine & $\begin{array}{c}\text { Gemcitabine: } 980.4 \mathrm{mg} / \mathrm{m}^{2} \\
\text { Vinorelbine: } 26.1 \mathrm{mg} / \mathrm{m}^{2}\end{array}$ & 2 cycles & $\mathrm{PD}$ & & $\begin{array}{l}\text { Disease } \\
\text { progression }\end{array}$ & 1050 \\
\hline & Gefitinib & $250 \mathrm{mg} /$ body & 646 days & $\mathrm{SD}$ & & $\begin{array}{l}\text { Disease } \\
\text { progression }\end{array}$ & 652 \\
\hline & Docetaxel & $65.4 \mathrm{mg} / \mathrm{m}^{2}$ & 4 cycles & $\mathrm{SD}$ & & $\begin{array}{l}\text { Completion of } \\
\text { designed cycles }\end{array}$ & 422 \\
\hline & Pemetrexed & $500.0 \mathrm{mg} / \mathrm{m}^{2}$ & 2 cycles & $\mathrm{PD}$ & & $\begin{array}{l}\text { Disease } \\
\text { progression }\end{array}$ & 342 \\
\hline & Erlotinib & $150 \mathrm{mg} /$ body & 50 days & $\mathrm{SD}$ & & $\begin{array}{l}\text { Adverse } \\
\text { reaction }\end{array}$ & 265 \\
\hline & Cisplatin/S-1 & $\begin{array}{l}\text { Cisplatin: } 58.8 \mathrm{mg} / \mathrm{m}^{2} \\
\text { S-1: } 120 \mathrm{mg} / \text { body }\end{array}$ & 4 cycles & $\mathrm{SD}$ & & $\begin{array}{l}\text { Completion of } \\
\text { designed cycles }\end{array}$ & 78 \\
\hline \multirow{4}{*}{9} & Carboplatin/Paclitaxel & $\begin{array}{c}\text { Carboplatin: } \\
\text { AUC }=5.6(\mathrm{mg} / \mathrm{l}) \cdot \mathrm{hr} \\
\text { Paclitaxel: } 175.1 \mathrm{mg} / \mathrm{m}^{2}\end{array}$ & 4 cycles & PR & \multirow{4}{*}{25.0} & $\begin{array}{l}\text { Completion of } \\
\text { designed cycles }\end{array}$ & 1056 \\
\hline & Carboplatin/Gemcitabine & $\begin{array}{c}\text { Carboplatin: } \\
\text { AUC }=1.8(\mathrm{mg} / \mathrm{l}) \cdot \mathrm{hr} \\
\text { Gemcitabine: } 987.3 \mathrm{mg} / \mathrm{m}^{2}\end{array}$ & 3 cycles & $\mathrm{PD}$ & & $\begin{array}{l}\text { Disease } \\
\text { progression }\end{array}$ & 657 \\
\hline & Pemetrexed & $500.0 \mathrm{mg} / \mathrm{m}^{2}$ & 2 cycles & $\mathrm{SD}$ & & $\begin{array}{l}\text { Inadequate } \\
\text { effect }\end{array}$ & 608 \\
\hline & Docetaxel & $74.7 \mathrm{mg} / \mathrm{m}^{2}$ & 4 cycles & SD & & $\begin{array}{l}\text { Completion of } \\
\text { designed cycles }\end{array}$ & 210 \\
\hline
\end{tabular}

* One cycle of weekly carboplatin/paclitaxel concurrent radiation therapy was conducted between cycles of this therapy.

S-1, combination capsule that contains tegafur, gimeracil, and oteracil potassium. Dose of S-1 indicated tegafur dose.

AUC, area under the blood time-concentration curve; BEV-CP, combination therapy with bevacizumab/carboplatin/paclitaxel; PR, partial response; $\mathrm{SD}$, stable disease; $\mathrm{PD}$, progressive disease.

\section{Efficacy}

The effectiveness of the BEV-CP therapy is shown in Figure 2. No patients showed complete response in either the FLT or non-FLT groups. The RR was $72.2 \%$ in the FLT group and $61.5 \%$ in the non-FLT group. The $\mathrm{RR}$ of the non-FLT group was lower than that of the FLT group, although the difference did not reach statistical significance $(\mathrm{p}=0.40)$. The DCR in the non-FLT group was higher $(92.3 \%)$ than that in the FLT group $(83.3 \%)$, although the difference did not reach statistical significance $(\mathrm{p}=0.43)$. The effectiveness of the BEV-CP therapy in the non-FLT group was similar to that of CBDCA and PTX previously administered combination therapy.

The Kaplan-Meier PFS curve for each group is shown in Figure 3. The median PFS time was 240 days in the FLT group and 258 days in the non-FLT group, which was not statistically significant $(\mathrm{p}=0.84)$.

\section{Adverse effects}

The hematologic toxicity and abnormal laboratory data collected during the course of the BEV-CP therapy are shown in Table 3, and other adverse effects are shown in Table 4. The rate of occurrence of increased gammaglutamyl transpeptidase of all grades in the non-FLT group was significantly lower than that in the FLT group, but the rate of occurrence of the other adverse effects was not statistically significant between the 2 groups. The $4 \mathrm{BEV}-\mathrm{CP}$ patients in whom therapy was discontinued in the FLT group because of adverse effects were treated with other chemotherapy regimens. 
Table 2-c. Drugs Administered to the Non-first-line Therapy Group Before the Administration of Bevacizumab/carboplatin/paclitaxel Combination Therapy (Case No. 10-13).

\begin{tabular}{|c|c|c|c|c|c|c|c|}
\hline $\begin{array}{l}\text { Case } \\
\text { no. }\end{array}$ & $\begin{array}{l}\text { Previously treated } \\
\text { regimen }\end{array}$ & Dose & Cycles & $\begin{array}{l}\text { Cytore- } \\
\text { ductive } \\
\text { effect }\end{array}$ & $\begin{array}{l}\text { Re- } \\
\text { sponse } \\
\text { rate (\%) }\end{array}$ & $\begin{array}{l}\text { Reason for } \\
\text { completion of } \\
\text { therapy }\end{array}$ & $\begin{array}{l}\text { Days from completion } \\
\text { of therapy to starting } \\
\text { BEV-CP therapy }\end{array}$ \\
\hline \multirow{2}{*}{10} & $\begin{array}{l}\text { Carboplatin/Paclitaxel } \\
\text { (adjuvant therapy) }\end{array}$ & $\begin{array}{c}\text { Carboplatin: } \\
\text { AUC }=6.1(\mathrm{mg} / \mathrm{l}) \cdot \mathrm{hr} \\
\text { Paclitaxel: } 169.5 \mathrm{mg} / \mathrm{m}^{2}\end{array}$ & 2 cycles & - & \multirow{2}{*}{0} & $\begin{array}{l}\text { Completion of } \\
\text { designed cycles }\end{array}$ & 1736 \\
\hline & Carboplatin/Paclitaxel & $\begin{array}{c}\text { Carboplatin: } \\
\text { AUC }=5.9(\mathrm{mg} / \mathrm{l}) \cdot \mathrm{hr} \\
\text { Paclitaxel: } 189.7 \mathrm{mg} / \mathrm{m}^{2}\end{array}$ & 4 cycles & $\mathrm{SD}$ & & $\begin{array}{l}\text { Completion of } \\
\text { designed cycles }\end{array}$ & 343 \\
\hline 11 & Carboplatin/Paclitaxel & $\begin{array}{c}\text { Carboplatin: } \\
\text { AUC }=5.7(\mathrm{mg} / \mathrm{l}) \cdot \mathrm{hr} \\
\text { Paclitaxel: } 192.3 \mathrm{mg} / \mathrm{m}^{2}\end{array}$ & 4 cycles & $\mathrm{SD}$ & 0 & $\begin{array}{l}\text { Completion of } \\
\text { designed cycles }\end{array}$ & 561 \\
\hline \multirow{5}{*}{12} & $\begin{array}{l}\text { Carboplatin/Paclitaxel } \\
\text { (adjuvant therapy) }\end{array}$ & $\begin{array}{c}\text { Carboplatin: } \\
\text { AUC }=6.0(\mathrm{mg} / \mathrm{l}) \cdot \mathrm{hr} \\
\text { Paclitaxel: } 173.6 \mathrm{mg} / \mathrm{m}^{2}\end{array}$ & 2 cycles & - & \multirow{5}{*}{25.0} & $\begin{array}{l}\text { Completion of } \\
\text { designed cycles }\end{array}$ & 2414 \\
\hline & Gemcitabine/Vinorelbine & $\begin{array}{c}\text { Gemcitabine: } 979.0 \mathrm{mg} / \mathrm{m}^{2} \\
\text { Vinorelbine: } 24.5 \mathrm{mg} / \mathrm{m}^{2}\end{array}$ & 3 cycles & PR & & $\begin{array}{l}\text { Completion of } \\
\text { designed cycles }\end{array}$ & 2017 \\
\hline & Carboplatin/Paclitaxel & $\begin{array}{c}\text { Carboplatin: } \\
\text { AUC }=5.9(\mathrm{mg} / \mathrm{l}) \cdot \mathrm{hr} \\
\text { Paclitaxel: } 172.4 \mathrm{mg} / \mathrm{m}^{2}\end{array}$ & 4 cycles & $\mathrm{SD}$ & & $\begin{array}{l}\text { Completion of } \\
\text { designed cycles }\end{array}$ & 477 \\
\hline & Pemetrexed & $500.0 \mathrm{mg} / \mathrm{m}^{2}$ & 4 cycles & $\mathrm{SD}$ & & $\begin{array}{l}\text { Completion of } \\
\text { designed cycles }\end{array}$ & 177 \\
\hline & Docetaxel & $60.7 \mathrm{mg} / \mathrm{m}^{2}$ & 4 cycles & $\mathrm{SD}$ & & $\begin{array}{c}\text { Completion of } \\
\text { designed cycles }\end{array}$ & 71 \\
\hline \multirow{4}{*}{13} & Carboplatin/Paclitaxel*1 & $\begin{array}{c}\text { Carboplatin: } \\
\text { AUC }=5.6(\mathrm{mg} / \mathrm{l}) \cdot \mathrm{hr} \\
\text { Paclitaxel: } 175.2 \mathrm{mg} / \mathrm{m}^{2}\end{array}$ & 2 cycles & PR & \multirow{4}{*}{25.0} & $\begin{array}{l}\text { Completion of } \\
\text { designed cycles }\end{array}$ & 1100 \\
\hline & Docetaxel & $59.4 \mathrm{mg} / \mathrm{m}^{2}$ & 3 cycles & $\mathrm{SD}$ & & $\begin{array}{l}\text { Inadequate } \\
\text { effect }\end{array}$ & 622 \\
\hline & Carboplatin/Gemcitabine & $\begin{array}{c}\text { Carboplatin: } \\
\text { AUC }=2.4(\mathrm{mg} / \mathrm{l}) \cdot \mathrm{hr} \\
\text { Gemcitabine: } 979.0 \mathrm{mg} / \mathrm{m}^{2}\end{array}$ & 1 cycle & $-* 2$ & & $\begin{array}{l}\text { Adverse } \\
\text { reaction }\end{array}$ & 482 \\
\hline & Cisplatin/S-1 & $\begin{array}{l}\text { Cisplatin: } 59.4 \mathrm{mg} / \mathrm{m}^{2} \\
\text { S-1: } 100 \mathrm{mg} / \text { body }\end{array}$ & 4 cycles & $\mathrm{SD}$ & & $\begin{array}{l}\text { Completion of } \\
\text { designed cycles }\end{array}$ & 309 \\
\hline
\end{tabular}

${ }^{* 1}$ This therapy was conducted followed by 2 cycles of weekly carboplatin/paclitaxel concurrent radiation therapy. ${ }^{* 2}$ Treatment was discontinued before efficacy was assessed.

S-1, combination capsule that contains tegafur, gimeracil, and oteracil potassium. Dose of S-1 indicated tegafur dose.

AUC, area under the blood time-concentration curve; BEV-CP, combination therapy with bevacizumab/carboplatin/paclitaxel; PR, partial response; $\mathrm{SD}$, stable disease; $\mathrm{PD}$, progressive disease.

BEV-CP therapy was discontinued after 1 cycle in 3 of the 4 patients and after 2 cycles in the remaining patient. The reasons for discontinuation were colon perforation; thromboembolic events; severe eruption; deterioration of general condition because of severe anorexia and diarrhea, and fatigue, nausea, and hyponatremia, each of which developed in 1 of the 4 patients. BEV-CP therapy was discontinued in 1 patient in the non-FLT group owing to severe peripheral neuropathy. This patient received 3 cycles of BEV-CP therapy, and the cytoreductive effect was a partial response; therefore, the patient was placed on maintenance therapy. One patient in the non-FLT group developed transient ischemic attacks. This patient received 4 cycles of BEV-CP therapy but was not placed on maintenance therapy. The discon- tinuation rate was lower in the non-FLT group $(7.7 \%)$ than in the FLT group (22.2\%), but the difference did not reach statistical significance $(\mathrm{p}=0.28)$.

The adverse effects reported during maintenance therapy are shown in Table 5. In the FLT group, 14 of the 18 patients received maintenance therapy. Four patients who discontinued the BEV-CP therapy because of adverse effects did not receive maintenance therapy. In the non-FLT group, 9 of the 13 patients received maintenance therapy. In the non-FLT group, 1 patient discontinued BEV-CP therapy because of disease progression, 1 developed transient ischemic attacks in response to the therapy, and 2 patients who completed 4 cycles of BEV-CP therapy had not started maintenance therapy as of September 1,2011. The adverse effects of the main- 


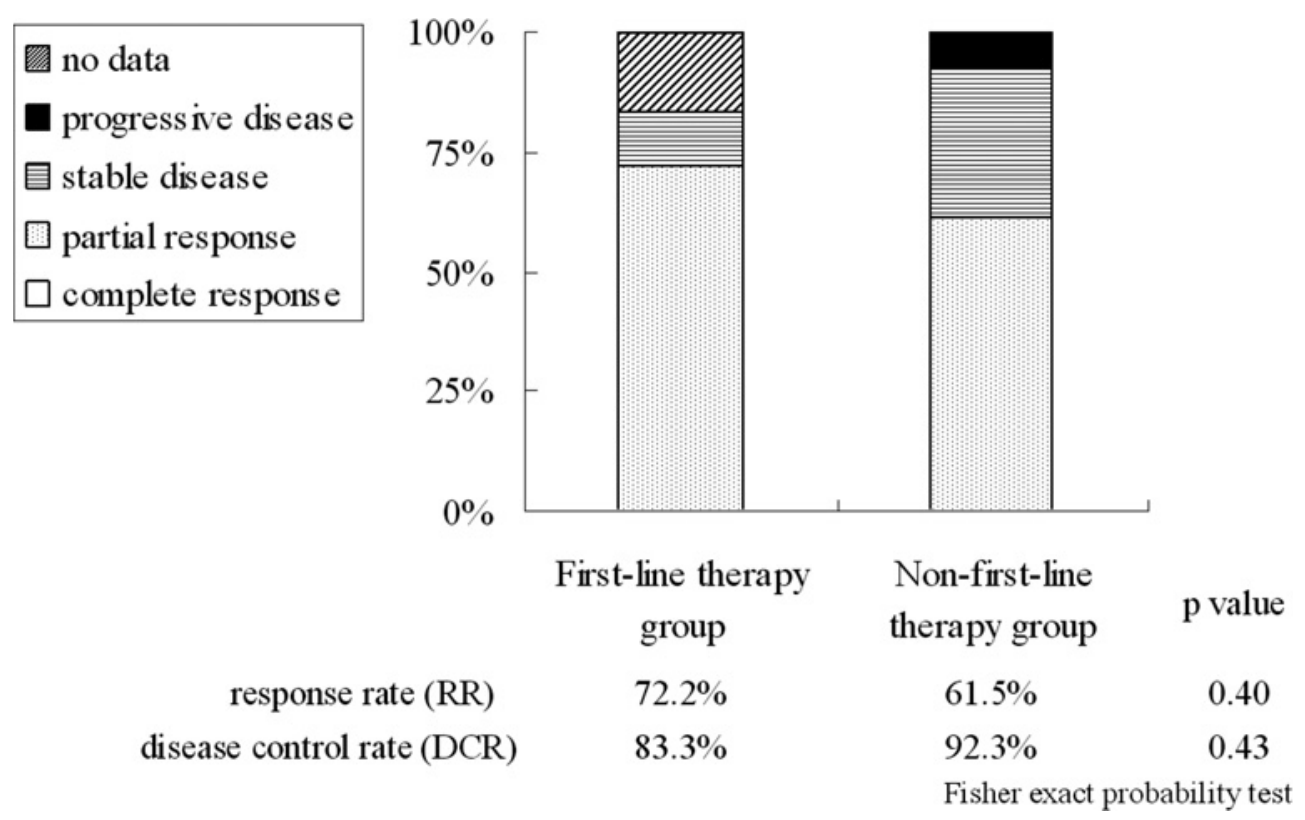

Figure 2. The cytoreductive effect with bevacizumab/carboplatin/paclitaxel combination therapy. The response rate (RR) was calculated by dividing the number of patients whose cytoreductive effect was better than a partial response by the total number of patients in each group. The disease control rate (DCR) was calculated by dividing the number of patients who achieved an improved cytoreductive effect due to stable disease by the total number of patients in each group.

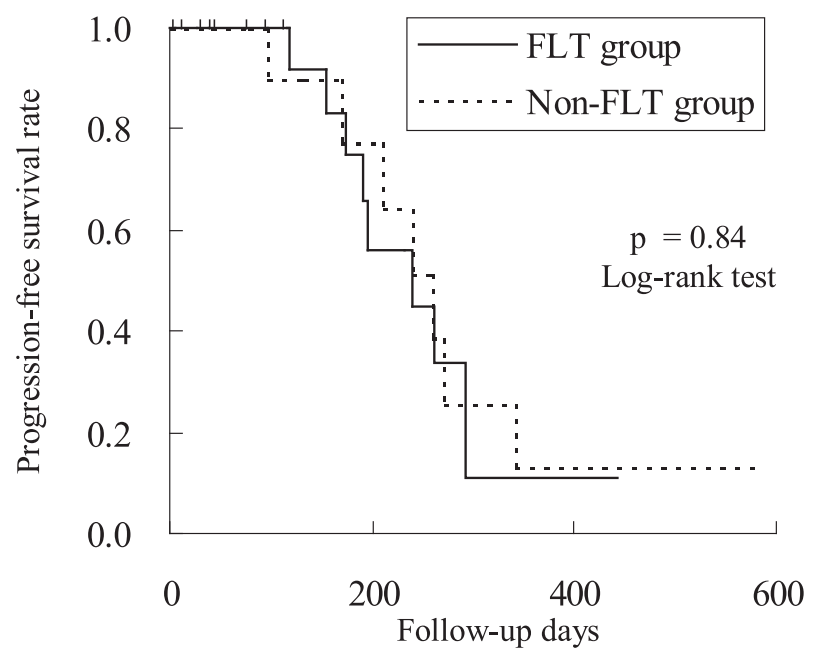

Figure 3. The progression-free survival rate in first-line therapy and non-first-line therapy patients. Vertical bar on graph shows censored cases. FLT means first-line therapy.

tenance therapy were few, and the occurrence rates of such adverse effects were not statistically significant between the 2 groups.

\section{DISCUSSION}

In the present study, the patient population was divided into 2 groups based on whether or not they had been treated with chemotherapy before the administration of the BEV-CP therapy, and the efficacy and the tolerability of BEV-CP therapy in the 2 groups were compared. The RR, DCR, and PFS results did not show statistically significant differences between the 2 groups, indicating that the effect of BEV-CP therapy are similar effective in patients previously treated with other chemotherapy regimens.

The rate of discontinuation of BEV-CP therapy due to adverse effects in the non-FLT group was lower than that in the FLT group, but this difference did not reach statistical significance. In addition, the rates of occurrence of adverse effects during the BEV-CP therapy were not statistically significant between the 2 groups, except for the increase in gamma-glutamyl transpeptidase. In particular, the rate of occurrence of hypertension, proteinuria, digestive tract perforation, thromboembolic events, and transient ischemic attacks, which are characteristic adverse effects of BEV, did not show 
Table 3. Hematological Toxicity and Abnormal Laboratory Data That Developed with Bevacizumab/ carboplatin/paclitaxel Combination Therapy

\begin{tabular}{|c|c|c|c|c|c|c|}
\hline & \multicolumn{2}{|c|}{$\begin{array}{l}\text { First-line therapy group } \\
\qquad(\mathrm{n}=18)\end{array}$} & \multicolumn{2}{|c|}{$\begin{array}{l}\text { Non-first-line therapy } \\
\text { group }(\mathrm{n}=13)\end{array}$} & \multicolumn{2}{|c|}{$\mathrm{p}$ value } \\
\hline & all grades & $\geq$ grade 3 & all grades & $\geq$ grade 3 & all grades & $\geq$ grade 3 \\
\hline WBC decreased & $16(89)$ & $12(67)$ & $13(100)$ & $7(54)$ & 0.33 & 0.36 \\
\hline Neutrophil count decreased & $17(94)$ & $15(83)$ & $13(100)$ & $13(100)$ & 0.58 & 0.18 \\
\hline Anemia & $16(89)$ & $2(11)$ & $13(100)$ & $3(23)$ & 0.33 & 0.34 \\
\hline Platelet count decreased & $15(83)$ & $5(28)$ & $12(92)$ & $2(15)$ & 0.43 & 0.36 \\
\hline AST increased & $3(17)$ & 0 & $2(15)$ & 0 & 0.66 & - \\
\hline ALT increased & $4(22)$ & 0 & $2(15)$ & 0 & 0.50 & - \\
\hline GGT increased & $11(61)$ & 0 & $3(23)$ & 0 & 0.04 & - \\
\hline Creatinine increased & $3(17)$ & 0 & $1(8)$ & 0 & 0.43 & - \\
\hline Hyponatremia & $12(67)$ & $2(11)$ & $6(46)$ & $3(23)$ & 0.22 & 0.34 \\
\hline Hypokalemia & $8(44)$ & $2(11)$ & $3(23)$ & 0 & 0.20 & 0.33 \\
\hline Hyperkalemia & $3(17)$ & 0 & $3(23)$ & 0 & 0.50 & - \\
\hline INR increased & $4(22)$ & 0 & $2(15)$ & 0 & 0.50 & - \\
\hline
\end{tabular}

statistically significant differences between the 2 groups. These results indicate the tolerability of BEV$\mathrm{CP}$ for patients who have received prior chemotherapy.

The RDI of BEV, CBDCA, PTX, and the average-RDI in the non-FLT group were lower than those in the FLT group. In particular, the RDI of CBDCA and the average-RDI were significantly lower in the non-FLT group. In the non-FLT group, the mean (SD) first dose of CBDCA was lower $(0.90(0.11)$ vs. $0.96(0.06) ; \mathrm{p}=0.38$, Mann-Whitney $U$ test), the rate of reduction of the dose of PTX during the BEV-CP therapy was higher $(53.8 \%$ vs. $22.2 \%$; $=0.08$, Fisher exact probability test), and the mean (SD) number of days between cycles of the BEV$\mathrm{CP}$ therapy was longer (26.2 (8.0) vs. 23.2 (5.6); $\mathrm{p}=0.12$, Mann-Whitney $U$ test) in comparison with the FLT group. The dose-limiting toxicity of CBDCA and PTX was based on bone marrow suppression. ${ }^{5}$ In the nonFLT group, the dose of CBDCA and PTX was often reduced because of bone marrow suppression and the administration interval was often extended because the recovery from bone marrow suppression was delayed. This may explain the lower RDI of each drug and the average-RDI in the non-FLT group. When patients who had previously received $\mathrm{CBDCA}$ and PTX combination therapy were treated with $\mathrm{BEV}-\mathrm{CP}$, it was necessary to carefully determine the dose of CBDCA and PTX and to control the administration intervals by considering the adverse effects developed in previous chemotherapy and by monitoring patients' condition. On the other hand, it was interesting that lowering the average-RDI in the non-FLT group did not lead to a reduction in efficacy in the present study.

The efficacy of BEV for colon cancer patients who have received prior chemotherapy has been reported. ${ }^{6}$ However, combination therapy with BEV for advanced NSCLC has been recommended only as first-line chemotherapy according to the JLCS guidelines ver. 20101,2 (The Japan Lung Cancer Society. "Clinical Guideline for Lung Cancer ver. 2010.”: < http://www.haigan.gr.jp/>, cited 20 April 2012). The use of docetaxel, ${ }^{7-9}$ pemetrexed, ${ }^{10-13}$ and erlotinib ${ }^{14,15}$ was recommended in the JLCS guidelines ver. 2010 as second-line therapy for patients treated with cytotoxic agents as FLT. Takeda et al. reported that a platinum doublet was selected in 20$30 \%$ of patients as second-line therapy, and in $10-15 \%$ of patients as third-line therapy by physicians in clinical practice (Presented at The 51st Annual Meeting of the Japanese Lung Cancer Society, International Conference Center Hiroshima, Hiroshima, on 3 November, 2010). However, the NSCLC patients without a mutated epidermal growth factor receptor gene had a less favorable prognosis. If the performance status of patient permits and it is thought that the patient could tolerate the adverse effects of platinum doublet when disease pro- 
Table 4. Side Effects That Developed with Bevacizumab/carboplatin/paclitaxel Combination Therapy, Excluding Hematological Toxicity and Abnormal Laboratory Data

\begin{tabular}{|c|c|c|c|c|c|c|}
\hline & \multicolumn{2}{|c|}{$\begin{array}{l}\text { First-line therapy group } \\
\qquad(\mathrm{n}=18)\end{array}$} & \multicolumn{2}{|c|}{$\begin{array}{l}\text { Non-first-line therapy } \\
\text { group }(\mathrm{n}=13)\end{array}$} & \multicolumn{2}{|c|}{$\mathrm{p}$ value } \\
\hline & all grades & $\geq$ grade 3 & all grades & $\geq$ grade 3 & all grades & $\geq$ grade 3 \\
\hline Hypertension & $14(78)$ & $6(33)$ & $11(85)$ & $5(38)$ & 0.50 & 0.75 \\
\hline Proteinuria & $5(28)$ & 0 & $1(8)$ & 0 & 0.18 & - \\
\hline Epistaxia & $10(56)$ & 0 & $8(62)$ & 0 & 0.52 & - \\
\hline Hemorrhoidal hemorrhage & 0 & 0 & $1(8)$ & 0 & 0.42 & - \\
\hline Hematuria & $1(6)$ & 0 & 0 & 0 & 0.58 & - \\
\hline Febrile neutropenia & $3(17)$ & $2(11)$ & 0 & 0 & 0.18 & 0.33 \\
\hline Nausea & $9(50)$ & $2(11)$ & $6(46)$ & $1(8)$ & 0.56 & 0.62 \\
\hline Vomiting & $1(6)$ & $1(6)$ & 0 & 0 & 0.58 & 0.58 \\
\hline Anorexia & $13(72)$ & $4(22)$ & $11(85)$ & $6(46)$ & 0.70 & 0.15 \\
\hline Dysgeusia & 0 & - & $3(23)$ & - & 0.06 & - \\
\hline Constipation & $14(78)$ & 0 & $8(62)$ & 0 & 0.28 & - \\
\hline Diarrhea & $5(28)$ & $1(6)$ & $8(62)$ & $1(8)$ & 0.07 & 0.67 \\
\hline Malaise & $13(72)$ & - & $11(85)$ & - & 0.70 & - \\
\hline Peripheral neuropathy & $16(89)$ & 0 & $13(100)$ & $2(15)$ & 0.33 & 0.17 \\
\hline Myalgia & $14(78)$ & 0 & $10(77)$ & 0 & 0.64 & - \\
\hline Arthralgia & $10(56)$ & 0 & $9(69)$ & 0 & 0.35 & - \\
\hline Alopecia & $14(78)$ & - & $9(69)$ & - & 0.45 & - \\
\hline Mucositis oral & $2(11)$ & 0 & $4(31)$ & $1(8)$ & 0.18 & 0.42 \\
\hline Cheilitis & 0 & 0 & $1(8)$ & $1(8)$ & 0.42 & 0.42 \\
\hline Skin disorders & 0 & 0 & $1(8)$ & 0 & 0.42 & - \\
\hline Rash maculopapular & $7(39)$ & $4(22)$ & $4(31)$ & $1(8)$ & 0.47 & 0.28 \\
\hline Pruritus & $5(28)$ & $2(11)$ & $5(38)$ & 0 & 0.40 & 0.33 \\
\hline Hiccups & $1(6)$ & 0 & $3(23)$ & 0 & 0.19 & - \\
\hline Edema limbs & $3(17)$ & 0 & $4(31)$ & 0 & 0.31 & - \\
\hline Transient ischemic attacks & 0 & - & $1(8)$ & - & 0.42 & - \\
\hline Colon perforation & $1(6)$ & $1(6)$ & 0 & 0 & 0.58 & 0.58 \\
\hline Thromboembolic events & $1(6)$ & $1(6)$ & 0 & 0 & 0.58 & 0.58 \\
\hline
\end{tabular}

Fisher exact probability test.

The data are shown by the number of patients (\%).

Table 5. Side Effects Developed with Maintenance Therapy Using Bevacizumab

\begin{tabular}{lcccccc}
\hline & \multicolumn{2}{c}{$\begin{array}{c}\text { First-line therapy group } \\
(\mathrm{n}=14)\end{array}$} & $\begin{array}{c}\text { Non-first-line therapy } \\
\text { group }(\mathrm{n}=9)\end{array}$ & \multicolumn{2}{c}{$\mathrm{p}$ value } \\
\cline { 2 - 6 } & all grades & $\geq$ grade 3 & all grades & $\geq$ grade 3 & all grades & $\geq$ grade 3 \\
\hline Anemia & $1(7)$ & 0 & 0 & 0 & 0.61 & - \\
ALT increased & $1(7)$ & 0 & 0 & 0 & 0.61 & - \\
GGT increased & 0 & 0 & $1(11)$ & 0 & 0.39 & - \\
Creatinine increased & $1(7)$ & 0 & $2(22)$ & 0 & 0.33 & - \\
Hyponatremia & $1(7)$ & $1(7)$ & 0 & 0 & 0.61 & 0.61 \\
Hypokalemia & $1(7)$ & 0 & $2(22)$ & 0 & 0.33 & - \\
INR increased & $1(7)$ & 0 & 0 & 0 & 0.61 & - \\
Hypertension & 0 & 0 & $1(11)$ & 0 & 0.39 & - \\
Proteinuria & $1(7)$ & 0 & $1(11)$ & 0 & 0.64 & - \\
Epistaxia & $1(7)$ & 0 & 0 & 0 & 0.61 & - \\
Mucositis oral & $1(7)$ & 0 & 0 & 0 & 0.61 & - \\
\hline
\end{tabular}

Fisher exact probability test.

The data are shown by the number of patients (\%).

ALT: alanine aminotransferase, GGT: gamma-glutamyl transpeptidase, INR: international normalized ratio. 
gression is confirmed, we think that re-treatment by platinum doublet might be one of the treatment options. In addition, if patient do not have a history of hemoptysis and tumor sites are not near large vessels, there is possibility that BEV could be administered in combination. The combination therapy with $\mathrm{BEV}$ is expected to prolong PFS, based on clinical trials as first-line therapy. While our study was intended for a few patients, our findings suggest that efficacy of BEV-CP therapy administered to patients as second-line therapy was similar to that of first-line therapy. In addition, tolerability of BEV-CP therapy administered as second-line therapy was also similar to that of first-line therapy by controlling the dose of CBDCA and PTX and administration intervals depending on patients' condition. In future, implementation of prospective clinical trials to estimate efficacy and tolerability of combination therapy with BEV administered as non-FLT is necessary.

本論文内容に関連する著者の利益相反：なし

\section{REFERENCES}

1. Sandler A, Gray R, Perry MC, Brahmer J, Schiller JH, Dowlati A, et al. Paclitaxel-carboplatin alone or with bevacizumab for non-small-cell lung cancer. $N$ Engl J Med. 2006;355:2542-2550.

2. Reck M, von Pawel J, Zatloukal P, Ramlau R, Gorbounova V, Hirsh V, et al. Phase III trial of cisplatin plus gemcitabine with either placeobo or bevacizumab as first-line therapy for nonsquamous non-small-cell lung cancer: AVAil. J Clin Oncol. 2009;27:1227-1234.

3. Sandler AB, Schiller JH, Gray R, Dimery I, Brahmer J, Samant M, et al. Retrospective evaluation of the clinical and radiographic risk factors associated with severe pulmonary hemorrhage in first-line advanced, unresectable non-small-cell lung cancer treated with Carboplatin and Paclitaxel plus bevacizumab. J Clin Oncol. 2009;27:14051412.

4. Socinski MA, Schell MJ, Peterman A, Bakri K, Yates S, Gitten R, et al. Phase III trial comparing a defined duration of therapy versus continuous therapy followed by second-line therapy in advanced-stage IIIB/IV nonsmall-cell lung cancer. J Clin Oncol. 2002;20:1335-1343.

5. Akiyama Y, Ohe Y, Tamura T, Sawada M, Inoue A, Kusaba H, et al. A dose escalation study of paclitaxel and carboplatin in untreated Japanese patients with advanced non-small cell lung cancer. Jpn J Clin Oncol. 2001;
31:482-487.

6. Giantonio BJ, Catalano PJ, Meropol NJ, O’Dwyer PJ, Mitchell EP, Alberts SR, et al. Bevacizumab in combination with oxaliplatin, fluorouracil, and leucovorin (FOLFOX4) for previously treated metastatic colorectal cancer: results from the Eastern Cooperative Oncology Group Study E3200. J Clin Oncol. 2007;25:1539-1544.

7. Fossella FV, DeVore R, Kerr RN, Crawford J, Natale RR, Dunphy F, et al. Randomized phase III trial of docetaxel versus vinorelbine or ifosfamide in patients with advanced non-small-cell lung cancer previously treated with platinum-containing chemotherapy regimens. The TAX 320 Non-Small Cell Lung Cancer Study Group. J Clin Oncol. 2000;18:2354-2362.

8. Shepherd FA, Dancey J, Ramlau R, Mattson K, Gralla R, O'Rourke M, et al. Prospective randomized trial of docetaxel versus best supportive care in patients with nonsmall-cell lung cancer previously treated with platinumbased chemotherapy. J Clin Oncol. 2000;18:2095-2103.

9. Mukohara T, Takeda K, Miyazaki M, Takifuji N, Terakawa K, Negoro S. Japanese experience with second-line chemotherapy with low-dose (60 mg/M2) docetaxel in patients with advanced non-small-cell lung cancer. Cancer Chemother Pharmacol. 2001;48:356-360.

10. Hanna N, Shepherd FA, Fossella FV, Pereira JR, De Marinis F, von Pawel J, et al. Randomized phase III trial of pemetrexed versus docetaxel in patients with non-small-cell lung cancer previously treated with chemotherapy. J Clin Oncol. 2004;22:1589-1597.

11. Scagliotti G, Hanna N, Fossella F, Sugarman K, Blatter J, Peterson P, et al. The differential efficacy of pemetrexed according to NSCLC histology: a review of two Phase III studies. Oncologist. 2009;14:253-263.

12. Ohe Y, Ichinose Y, Nakagawa K, Tamura T, Kubota K, Yamamoto N, et al. Efficacy and safety of two doses of pemetrexed supplemented with folic acid and vitamin B12 in previously treated patients with non-small cell lung cancer. Clin Cancer Res. 2008;14:4206-4212.

13. Cullen MH, Zatloukal P, Sörenson S, Novello S, Fischer JR, Joy AA, et al. A randomized phase III trial comparing standard and high-dose pemetrexed as second-line treatment in patients with locally advanced or metastatic non-small-cell lung cancer. Ann Oncol. 2008;19:939945.

14. Shepherd FA, Rodrigues Pereira J, Ciuleanu T, Tan EH, Hirsh V, Thongprasert S, et al. Erlotinib in previously treated non-small-cell lung cancer. $N$ Engl J Med. 2005;353: 123-132.

15. Kubota K, Nishiwaki Y, Tamura T, Nakagawa K, Matsui $\mathrm{K}$, Watanabe K, et al. Efficacy and safety of erlotinib monotherapy for Japanese patients with advanced nonsmall cell lung cancer: a phase II study. J Thorac Oncol. 2008;3:1439-1445. 